\title{
THE DRIVING FACTORS OF CHINA'S PUBLIC-PRIVATE PARTNERSHIP PROJECTS IN METROPOLITIAN TRANSPORTATION SYSTEMS: PUBLIC SECTOR'S VIEWPOINT
}

\author{
Jing-Feng Yuan ${ }^{1}$, Mirosław J. Skibniewski ${ }^{2}$, Qiming $\mathbf{L i}^{3}$, Jin Shan ${ }^{4}$ \\ ${ }^{1}$ Department of Construction and Real Estate, Southeast University, Nanjing, 210096, P. R. China; \\ Department of Civil and Environmental Engineering, University of Maryland, College Park, MD 20742, USA \\ ${ }^{2}$ Department of Civil \& Environmental Engineering, University of Maryland, College Park, MD 20742-3021, USA \\ ${ }^{3}$ Department of Construction Management and Real Estate, Southeast University, Nanjing, 210096, P. R. China \\ ${ }^{4}$ School of Transportation Engineering, Southeast University, Nanjing, 210096, P. R. China \\ E-mail: ${ }_{1}^{1} f y u a n @ s e u . e d u . c n ;{ }^{2}$ mirek@umd.edu; ${ }^{3}$ njlqming@163.com \\ Received 31 May 2009; accepted 17 Dec 2009
}

\begin{abstract}
In recent years, China needs far more financing for transportation infrastructure than can be provided by the government alone. Meanwhile the capacity of the Chinese government to provide public services on its own in an effective and efficient way is being questioned and reassessed at various levels. Accordingly, the involvement of private investors in the development of Metropolitan Transportation Systems (MTS) has been promoted by the Chinese public sector by means of adopting the Public Private Partnership (PPP) model. However, China's dynamic and complex political, financial, legal and regulatory environment makes the private sector adjust to accommodate the existing regime by way of understanding the driving factors in PPP applications for improving the chances of project success. This paper presents two case studies in China's MTS. Based on a case study and comprehensive literature review, 15 driving factors associated with PPP projects from the perspective of the Chinese public sector have been identified. A structured questionnaire survey targeting the public sector has been conducted to seek, analyze and integrate its perception of the driving factors. Through statistical analysis of the relative significance of each of these driving factors, the writers determined five common major dimensions of the Chinese public sector's purpose in developing PPP schemes, and the key factors that quantify each purpose. The establishment of the measures for these objectives and the key factors that quantify each of these purposes will likely be useful in encouraging private participation in infrastructure management and directing/concentrating efforts of the private sector to deliver quality public services under mutually beneficial long-term contractual arrangements.
\end{abstract}

Keywords: public private partnership, metropolitan transportation system, decision factors, factor analysis, public sector, infrastructure development.

\section{Introduction}

In recent years, China's demands for transportation infrastructure projects in urban development (e.g., highways, bridges, and tunnels) are largely driven by urbanization (Chen and Doloi 2008). Owing to the limited financial budget and inefficient experience in providing infrastructure products and services involving only the public sector, Chinese policymakers must find new ways to improve the performance of public projects and services to meet the demands (Chen and Doloi 2008; Wang et al. 2000; Zhang 1998; Chan et al. 2003). As a worldwide solution to involve greater private sector participation in the development of urban transportation projects, Public Private Partnerships (PPPs) have been applied in China for many years because of its attractive characteristics to transfer risks to the private partners, reduce public sector administration cost, solve the problem of public sector budget restraint, provide higher quality public products and services, and save time in delivering the projects, etc (Li et al. 2005a).

The prior research has involved the driving force of PPP projects in transportation or other industries. Li et al. indicate that PPP project procurement is perceived as most attractive in terms of positive factors relating to better project technology and economy, greater public benefit, public sector avoidance of regulatory and financial constraints, and public sector saving in transaction costs (Li et al. 2005a). Majamaa et al. indicate that the purpose of the public sector is not to directly monitor psychological changes in consumers or to predict future needs, but to meet existing demand for services. (Majamaa et al. 2008) PPP is recognized as one of the factors of infrastructure development to improve service efficiency (Skietrys et al. 2008). Chen and Subprasom conclude that some of the forces driving PPP movement include: a scarcity of public resources, an increase in the demand for better service, and political trend toward the 
deregulation of infrastructures from public monopoly (Chen and Subprasom 2007).

However, China is in dynamic transition and new issues and lessons emerge every day. Meanwhile, the Chinese construction market is a buyer's market dominated by owners, which means the public sectors would dominate the PPP projects to satisfy their needs (Meng 2002). Therefore, the private sectors in Chinese PPP projects have to face huge challenges result from the change of policy, law and regulations. As stated by Chen and Doloi, as well as UNIDO (Chen and Doloi 2008; UNIDO 1996), PPP projects are complex from both financial and legal points of view. PPPs require time to develop and negotiate. The involvement and support of Chinese government are also important. A suitable political and economic climate, political stability, a defined and stable legal and regulatory environment and a freely convertible currency, as well as other appropriate elements for investment generally are absolutely necessary. As a result, it is necessary for the private sector of China to structurally adjust to accommodate the existing economic, financial, legal and regulatory environment, and furthermore to understand the driving factors in PPP applications in China's public sector to improve the chances of project success.

The goal of this paper is to identify the important driving factors of Chinese PPP projects based on the case study and literature review. The findings can also help both public and private parties to improve their understanding in planning and implementation of PPP projects to achieve a win-win result.

The remainder of this paper is organized as follows. Section 2 presents two case studies of PPP application in Chinese MTS. Section 3 provides an overview of driving factors in Chinese transportation projects based on the findings of case study and literature review. A structured questionnaire survey targeting the public sector is then presented in Section 4 to seek, analyze and integrate their perceptions of the driving factors. Factor analysis of the driving factors is provided in Section 5. Section 6 provides concluding remarks.

\section{PPP application case study in Chinese MTS system}

The goal of application of PPP in transportation projects has been recognized as potentially effective means of achieving local and national transportation goals (Lawther 2005). It is also specified by Francois (2001) as follows,

-Achieve and maintain an acceptable mobility level to satisfy local, regional, and national needs for the movement of people and things to their desired destinations;

- Minimize time delays caused by congestion;

- Maximize the safety of surface transportation by reducing the opportunities and propensities for crashes to a minimum.

In a PPP scheme, it often involves three parties: the government (public sector or client), whose objective is to maximize the benefit defined in terms of social welfare added to the society; the private investors, whose objec- tive is to maximize the profit generated from the investment; and the end users, whose objective is to minimize the inequality of benefit distribution among the users traveling from different origin-destination pairs (Chen and Subprasom 2007). Each of these parties has different objectives that often conflict with each other, which would result in the challenge of reaching the foregoing goals. The increasing different needs would make the achievement of goals more difficult for those transportation facilities in metropolis in China. Actually, the objective of Chinese public sector usually integrates the goal of itself and end user. Thus the demands of Chinese government are extremely huge. For example, China had invested over 35 billion US dollars (USD) in metropolitan urban rail transit system in last five years. Furthermore, China needs more than USD 60 billion to support new urban development in future five years (Xie, He 2005; Seneviratne 2006).

Facing huge gap of capital and lack of efficient public service delivery, many PPP projects have been implemented in Chinese metropolises by using the capital and management skills of private sectors. The following two cases would be helpful to put the sight into Chinese PPP projects in MTS.

\subsection{Case study of the 4th Beijing Metro Line}

The Special Purpose Vehicle (SPV) of the 4th Beijing Metro Line comprises Beijing Infrastructure Investment Corporation (BIIC), the Beijing Capital Group Ltd. (BGC), and the Hong Kong Metro Corporation (MTR). The former two companies are state-owned companies; the latter one is a private company from Hong Kong ( $\mathrm{Li}, \mathrm{J}$. and $\mathrm{Li}, \mathrm{Q}$ 2007). This SPV is responsible for investments and installations of metro vehicle and related electromechanical equipments, as well as the operation of 4th Beijing Metro Line (30 years, 2004-2033). This metro line is the first PPP project applied in Chinese Metropolitan Transportation System.

The project is divided into two parts based on the characteristics of construction missions (Parts $\mathrm{A}$ and $\mathrm{B}$ ). Investments in Part A are about USD 1.5 billion (70\% of the total investment) including levy land and remove; the construction of metro station, cave, depot, and parking; rail; civil defense. Part A is fulfilled by BIIC using the method of Design-Build. The use right of partial Part A can be bought by SPV after the Part A is finished (A1). The other part of Part A can be leased by SPV (A2). Investments in Part B are about USD 0.65 billion (30\% of total investments) including vehicle, automatic fare collection system, signal and communication system, air conditioning and ventilation system, water supply and drainage system, fire protection system, escalator and elevator, control equipment, and power-supply facilities. Part B is completed by SPV (Li, J. and Li, Q. 2007).

Because of Beijing 2008 Olympic Game, there are huge demands of investments in infrastructure development to build sports venues, to improve the quality of environment, and to enhance the transportation capability to satisfy the requirement of Olympic Game. Facing the budget constraints, the 4th Beijing Metro Line was then 


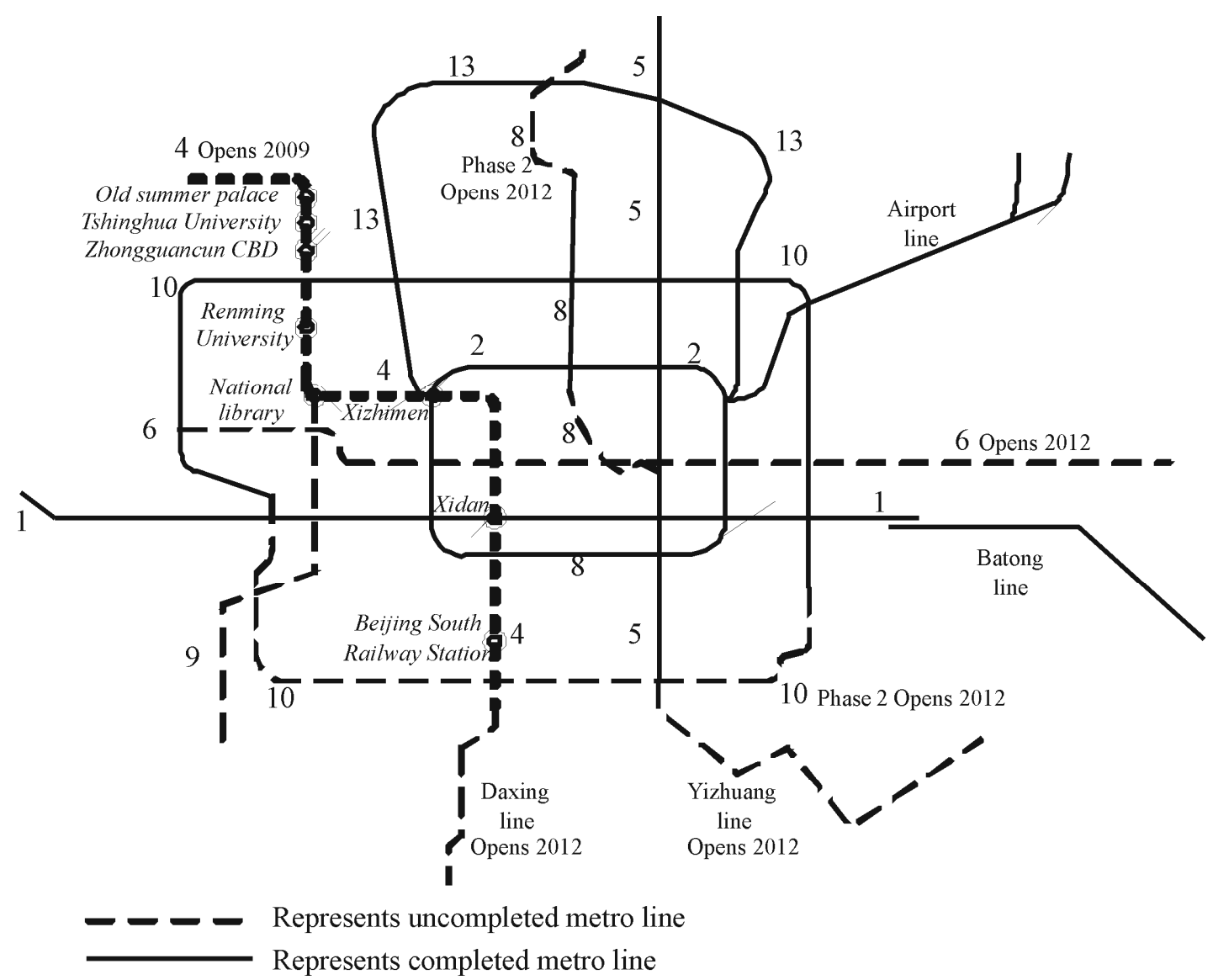

Fig. 1. Beijing Metro planning map for 2012

selected to collect the investments of the private sector by PPP model. Thus the first important driving factor in this case is to deal with the problem of financial bottleneck. At the same time, other related costs (e.g. administration costs and service costs) would also be reduced.

As shown in Fig. 1, the 4th Beijing Metro Line is in the west of Beijing from north to south, which will pass through many central business districts and universities (e.g. Tingshua University, Renming University, and Zhongguancun). Hence this line is called "Golden Line" by Chinese government, which is hopefully supposed to resolve the problem of congestion and provide better choice for going to work or school. Therefore, the public sectors want to learn experiences from MTR, who is managing Hong Kong Metro system and have achieved great success. These experiences and management skills can be applied in future development of urban rail transit system. Thus the second driving factor in this case is to transfer technology (technique and management skill) of private sectors. The objective of this case to relieve the traffic pressure can also be reached on the basis of excellent capability of private sectors.

The capital framework of project is shown in Fig. 2. In SPV, the shares of MTR, BCG, and BIIC are $49 \%$, $49 \%, 2 \%$ respectively. The local authority of Beijing singed concession agreement with SPV with 30 years concession period. In concession agreement, the standard of construction, operation and project transfer are specifically established. As of a fact, the price of leasing A2 is low for SPV, which can provide the opportunity to make a profit. Meanwhile this price can be adjusted based on the situation of operation (0). When the revenue is high, the price will be increased, which can regain the investments of public sectors and also avoid the excess profits of private sectors. Otherwise, the price will be decreased, which can help private sectors to reduce the operation cost and to reallocate risk by the change of passenger flow. This mechanism can properly allocate the market and financial risks, especially for public sectors. Another highlight in this PPP scheme is that the public client (BCG) undertakes most of time-consuming construction works, which are of the most risks and uncertainties for private sectors. At the same time BCG also invests $49 \%$ of Part B, which shares same risks with MTR. This kind of scheme is attractive for MTR in spite of many constraints in concession agreement (e.g. fixed price by government). In a word, transferring risks to private sectors is also a positive factor for public sectors.

\subsection{Case study of the Nanjing Yangtze River Tunnel}

As the capital of Jiangsu Province, Nanjing is a major metropolis in the east of China. The local authority of Nanjing is currently focusing on the urbanization to expand Nanjing's transportation system including more than ten metro lines, the light rail between Shanghai, Hangzhou and Nanjing, four bridges across the Yangtze River, and a Yangtze River Tunnel. These projects are scheduled for 


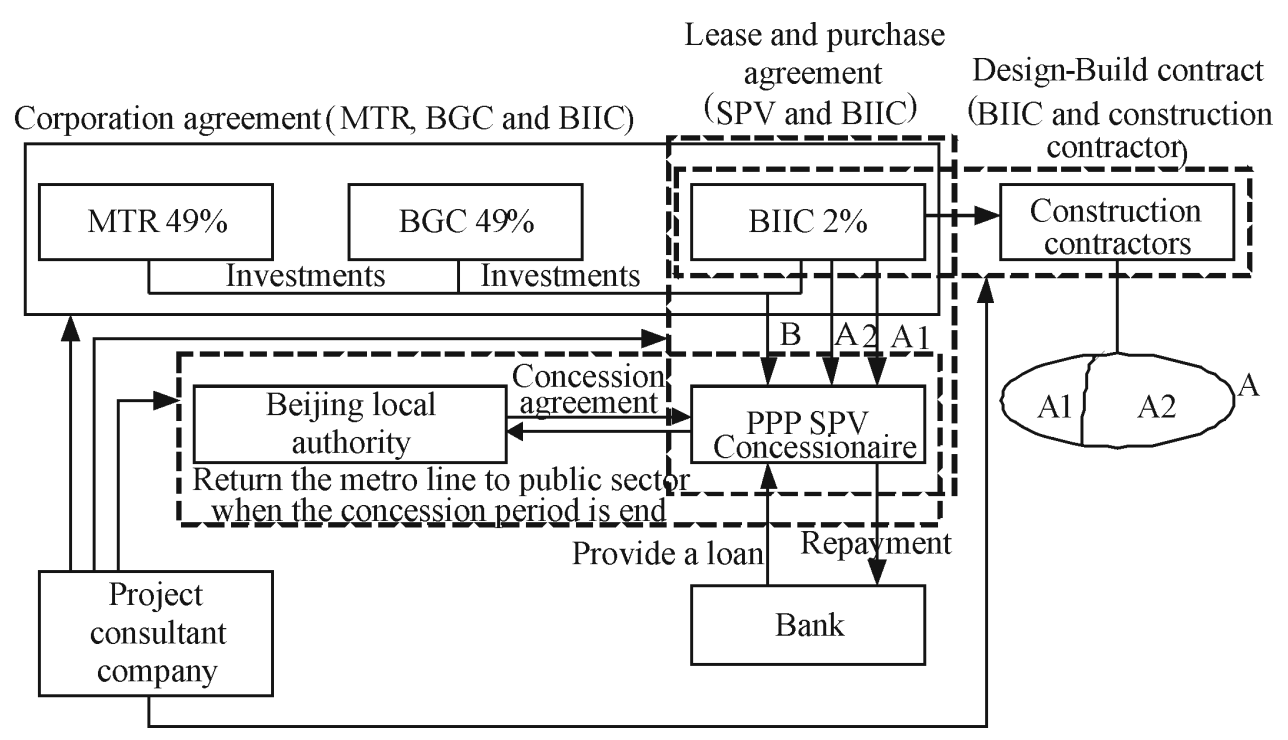

Fig. 2. The capital structure of the 4 th Beijing metro line

completion by 2020 . Therefore, a mix of private and public sector participants is introduced for the metro, bridge and tunnel projects to address the problem of lack of sufficient capital.

The length of the tunnel is 6,165 meters. Its design life is 100 years. The total investment is USD 0.45 billion. Finally, the SPV is composed of China Railway Construction Corporation Group (CRCC), Nanjing Transportation Corporation Group (NTC), and National Capital Management Company of Pukou District. The latter two companies are quasi-public clients, which raise $20 \%$ of the finance for the project. The remaining $80 \%$ is funded by CRCC, who holds 30 years of concession period (2005-2034). In this case, the first important driving factor is as same as the 4th Beijing Metro Line, which is also to deal with the problem of financial constraints. Not like the 4th Beijing Metro Line, the capital structure of Nanjing Yangtze River Tunnel is relatively simple, which can also appropriately allocate the risk amongst three partners and effectively transfer risks to the private sectors (CRCC). CRCC has participated in many transportation PPP projects in China including Jingcheng Highway in Beijing, Yuling Highway in Sichuan, Wuhan Yangtze River Tunnel, and Xianyang Bridge in Xian, whose experiences, quality technique, and management skills are the base for success (Zhao 2006).

The Nanjing Yangtze River Tunnel will be a fast passage connecting Nanjing main urban zone with industrial area of Nanjing, which would greatly improve the communication between northern and southern banks of Yangtze River, and further strengthen Nanjing's role as the transportation hub in eastern China and the downstream Yangtze River area. For many years, most of transport tasks have been undertaken by the 1st Nanjing Yangtze River Bridge (as shown in Fig. 3) since 1968. In recent years, the increasing traffic volume has exceeded the capability of this bridge, which limits the development of Nanjing. Although the 2nd and 3rd Nanjing Yangtze River Bridge have been finished in 2000 and 2005 , the huge demands can not be satisfied because they

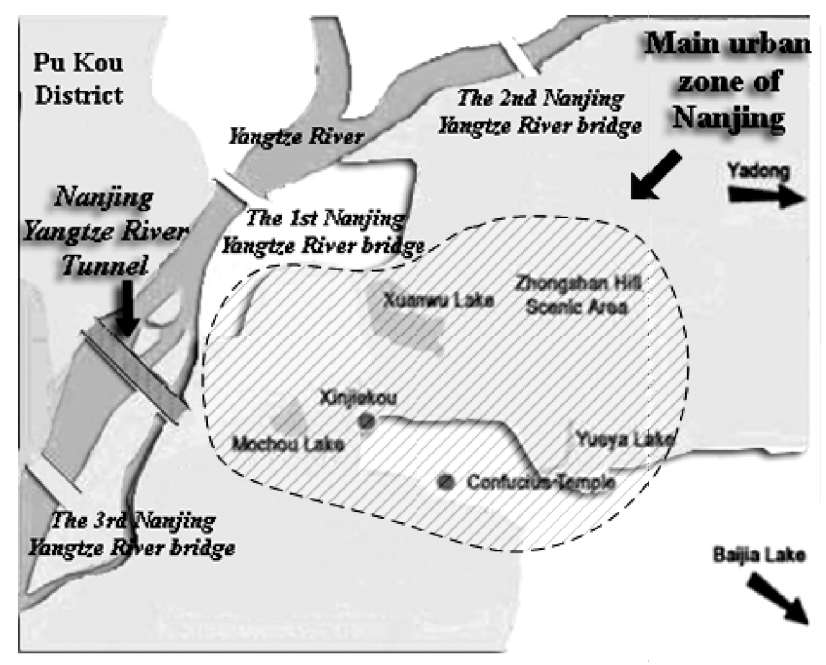

Fig. 3. The location of Nanjing Yangtze River Tunnel

are far away from main urban zone. Hence, in other words, the accomplishment of Nanjing Yangtze River Tunnel would not only benefit the local economic development, but also enable the SPV of this case to make high profits. Based on the prediction of CRCC, the equivalent numbers of passenger car units (PCUs) per day will reach 100,000 per day until 2010. More than $30 \%$ vehicles will use the tunnel $(0)$. Table 1 shows the estimation of PCUs until 2030. At the same time, the concession agreement indicates that the incomes of SPV will not only include toll, but also include advertising and

Table 1. Estimation of PCUs and revenue of Nanjing Yangtze River Tunnel

\begin{tabular}{c|c|c|c}
\hline Year & $\begin{array}{c}\text { Equivalent numbers } \\
\text { of passenger car } \\
\text { units per day }\end{array}$ & $\begin{array}{c}\text { Toll stan- } \\
\text { dard (PCU, } \\
\text { USD) }\end{array}$ & $\begin{array}{c}\text { Total revenue } \\
\text { per year } \\
\text { (Million USD) }\end{array}$ \\
\hline 2010 & 33440 & 3 & 36.11 \\
\hline 2020 & 60480 & 3 & 65.32 \\
\hline 2030 & 76626 & 3 & 82.76 \\
\hline
\end{tabular}


oil business revenue. The estimated financial data is shown Table 2. The estimation illuminates that the revenue stream is attractive to both of private and public sectors. Accordingly, the benefit of this PPP project also include promoting local economy, providing more convenient public service, and earning long-term stable revenue.

\section{View of driving factors}

As shown in above-mentioned two cases, China needs more and better transportation infrastructure to sustain the rapid economic growth and improve social welfare. Despite impressive gains, the rate and quality of infrastructure development can still be said to lag behind that needed to sustain the rapid economic growth, and is believed by the government to be the bottleneck (Chen and Doloi 2008; Yuan et al. 2009). In China, infrastructure used to be a public regime. Due to the administrative and fiscal decentralization policy, the revenue of the central government has been falling. As a result, local authorities, who are actually responsible for the infrastructure development, must rely on their own revenues and the market mechanism to sustain local infrastructure development. Local infrastructure funding traditionally comprises local tax revenue, loans, and extra-budgetary revenues that made up of user fees, ad hoc levies, asset-sales, etc (Meng 2002). To accommodate the big demands for infrastructure, local governments need new funding sources to invest the new projects. As a result, the private sector has an increasingly important role in infrastructure development, and PPP provides a vehicle for its participation in the traditional public regime. On the other side, many private sectors also want to obtain government sponsorship, guarantee and tax reduction by the way of corporation with public sectors, by which a good long-term stable partnership can be established. This kind of partnership is also a successful factor for PPP projects in many previous researches (Zhang 2005; Li et al. 2005b).

Many types of risk will be transferred to the private sector via the PPP model. The cases presented herein also show that risks related to financing, market, facility maintenance will all be transferred. Li et al. demonstrate that the transfer of risk is a primary objective in PPP project procurement (Li et al. 2005a). The public sectors seek to divest themselves of the risks associated with the delivery and operation of desired public facilities and services. Many of these risks relate to the completed time of construction work, construction cost, operation cost and service quality etc. Under current guidelines in China, the public sectors provide explicit information about risk allocation to confirmed private sector bidders during the contract procurement process for a project. In many real projects, public sectors try to transfer most of risks to private like the situation in the case of Nanjing Yangtze River Tunnel. However, it is likely that the private sector would agree that risk transfer is also a positive factor in its participation in PPP's. The fact is that risks have close relationship with future reward. Higher risks also suggest that private sector participants may obtain higher revenue that is they are enthusiastic about. In many Chinese MTS projects, the private sector is better than public sector to be responsible for design, build, operation, and maintenance. A large number of risks (e.g. project costs, traffic volume, financing) in MTS projects are unmanageable and uncontrollable for public sector. However, a strong private sector would be able to handle these risks and be glad to make profits by sustaining these risks. In the case of Nanjing Yangtze River Tunnel, it is the first time for local authority to build a tunnel under the Yangtze River (the largest river in China, and the third river in the world), which raises a potential for the private sector to help the government share and transfer the risk. The primary private sector firm - CRCC, which succeeded in the construction and operation of the Wuhan Yangtze River Tunnel, is experienced at thess types of projects and able to turn in profit from high-risk MTS projects.

Therefore, the concessionaire in Chinese MTS PPP projects should be selected studiously in accord with the requirements of the public sector. These major transportation projects in the metropolis require that the local government owner must select an appropriate private sector partner with appropriate experience, adequate technology and management skills to reduce the risk of inefficiency (Kumaraswamy and Anvuur 2008). Accordingly, the public agency anticipates to acquire advanced technology and management skills to manage other public projects or future PPP projects.

Additionally, there might be unforeseen increases in the capital costs of the projects, or higher than expected service delivery and maintenance costs (Li et al. 2005a). The uncertainty and risks inherent in public projects probably make public spend more financial resources on these projects without a PPP solution. Furthermore, because the private sector takes over the responsibility for design, construction, operation and maintenance, the public sector partner will no longer have day-to-day responsibilities for service delivery. This allows capping final service costs at pre-determined levels and substantially reducing facility administration costs. The public sector will thus take on a less intensive role of monitoring the performance

Table 2. Profitability indices of total investment in Nanjing Yangtze River Tunnel

\begin{tabular}{|c|c|c|c|c|c|c|c|c|c|c|}
\hline \multicolumn{6}{|c|}{ Total investment } & \multicolumn{5}{|c|}{ Own fund } \\
\hline \multicolumn{2}{|c|}{$\begin{array}{l}\text { Internal rate of return } \\
(\%)\end{array}$} & \multicolumn{2}{|c|}{ Payback period (year) } & \multicolumn{2}{|c|}{$\begin{array}{c}\text { Financial net pre- } \\
\text { sent value } \\
\text { (Million USD) }\end{array}$} & \multicolumn{2}{|c|}{$\begin{array}{l}\text { Internal rate of } \\
\text { return }(\%)\end{array}$} & \multicolumn{2}{|c|}{$\begin{array}{l}\text { Financial net } \\
\text { present value } \\
\text { (Million USD) }\end{array}$} & $\begin{array}{l}\text { Investment } \\
\text { profit rate } \\
(\%)\end{array}$ \\
\hline Before tax & $\begin{array}{c}\text { After } \\
\text { tax }\end{array}$ & Static & Dynamic & $\begin{array}{l}\text { Before } \\
\text { tax }\end{array}$ & $\begin{array}{l}\text { After } \\
\text { tax }\end{array}$ & $\begin{array}{l}\text { Before } \\
\text { tax }\end{array}$ & $\begin{array}{c}\text { After } \\
\text { tax }\end{array}$ & $\begin{array}{c}\text { Before } \\
\text { tax }\end{array}$ & $\begin{array}{l}\text { After } \\
\text { tax }\end{array}$ & \\
\hline 8.53 & 7.21 & 16.1 & 26.6 & 144.81 & 61.21 & 9.72 & 7.77 & 141.51 & 57.92 & 7.70 \\
\hline
\end{tabular}


of the private concessionaire and receiving periodic reports. Also, the public-sector partner avoids large nonrecurring investments and can arrange its own budget policy from a new starting point (Tieva and Junnonen 2009).

PPP procurement is seen as attractive to public and private sector participants because it forces a project to service any financial debt from the revenue streams derived from the project itself ( $\mathrm{Li}$ et al. 2005a). The revenue stream of a toll tunnel or a metro line is almost the only resource to earn money for the private sectors. Thus the private sectors have to try their best to reduce the costs and develop the market to make profits. This nonrecourse or limited recourse public funding is an important ingredient of PPP procurement (Akintoye et al. 2001). As a result, a well-managed project will be transferred to pubic, which is just that the public sectors are glad to see. Furthermore, the private sector can provide additional facilities/service beyond the basic requirements by the public sector partner in order to earn additional profit by using improved technology and management skills to operate the project by One more China-specific driving factor is that the Chinese government's anticipated structural reform intends to separate the administrative and commercial functions of government created many domestic private developers and quasi-private developers (Dimitriou and Trueb 2005). Their capabilities and resources are, however, still limited. An open market has not been realized and because of the lack of competition, efficiency is weak. Over the past two decades, the capacity of the Chinese government to provide public services on their own in an effective and efficient way is being questioned and reassessed at various levels and in different form. The main arguments stress that not only are government resources invariably inadequate but also that the quality and efficiency of the services they provide are very often rather poor (Pessoa 2008). Public services are frequently seen as ineffective in resource allocation and poor in management. Burdened with bureaucratic procedures, the public sector is usually incapable of acting quickly to adapt to change and, as a result, the services provided will deteriorate over time. Additionally, the public sector does not need to compete and thus it has no incentive to improve quality, particularly in situations where it is the only provider of services. The commercialization reform intends to improve the economy, efficiency and effectiveness of infrastructure projects and services that were traditionally a public welfare. The governments intend to use PPP as a stimulus to explore new direction in the reform and experimentally improve infrastructure product and service price on a local and project by project basis, as a pilot to improve the market prices generally (Chen and Doloi 2008). To commercialize the infrastructure products and services therefore becomes one driving factor in PPP applications in China.

Therefore, a total of 15 driving factors in China's Public Private Partnership Projects in MTS can be presented as follows. The identified driving factors received concurrence from the city government of Nanjing.

F1: Acceptable quality of project.
F2: Project within budget or under budget in construction and operation.

F3: Quality public service.

F4: On-time or early project completion.

F5: Solving public sector budget constraints.

F6: Provide timely and convenient service for the general public.

F7: Satisfying the need for public facilities.

F8: Life-cycle cost reduction.

F9: Introducing business and profit generating skills to the public sector.

F10: Transferring risk to private sector.

F11: Promoting local economic development.

F12: Making profit from public service.

F13: Improving technology level or allowing technology transfer.

F14: Public sector can acquire additional facilities/services beyond the minimum requirement from the private sector.

F15: Private sector can earn government sponsorship, guarantee and tax reduction.

When the 15 driving factors are satisfied, the public sector tends to improve the output of public projects by using the PPP method at two levels.

The first level focuses on the projects, paying particular attention to the intrinsic factors such as F1, F2, F3, F4, F6, F8, and F10. These factors integrate public sector's interests in improving project quality (F1), saving time (F4) and costs (F2 and F8), and providing better public service (F3 and F6). With respect to F1 and F3, the quality of construction and maintenance, and high level of service are respectively addressed by the private sector. The key benefits of PPPs in transferring high project risk (F10) to the private sector facilitate the development of PPPs, so that the private sector is expected to endure the majority of project-related risks in PPP projects. In the MTS system, however, this high risk can be controlled better by professional competence and relevant experienced of the private sector. The estimated revenue from MTS projects can meet the expectation of the private sector owing to rapid urban development in China, as shown in Case 2.

The second level of the 15 driving factors focuses on macroeconomic development, i.e. F5, F7, F9, F11, F12, F13, F14 and F15. These factors reflect the needs of the public sector in transportation management. As presented by Ehrlich and Tiong (2008), the government is mainly responsible for macroeconomic policies. Thus, focusing on these factors, the public sector wishes to address a number of social problems with the help of PPPs. For example, the public sector addresses budget constraints (F5) and satisfies the need for new public facilities (F7). Meanwhile, collaborating with the private sector and attracting private investment in public projects helps attain business and income generating skills (F9, learned from Case 1), promote local economic development (F11, learned from Case 2), and obtain additional facilities/services by the engagement of the private sector (F14). For the public sector, the attractiveness of PPP projects related to MTS systems is a longterm stable revenue stream (F12) secured through the 
partnership mechanism. The public sector also expects to establish a good relationship with a strong private sector through government sponsorship or guarantees (F15). Furthermore, the private sector is expected to introduce advanced technology and expedite technology transfer and innovation (F13) while addressing complex technical problems in PPPs.

\section{Research survey}

\subsection{Research design and administration}

A structured questionnaire survey was conducted from January through March 2008. The survey targets were limited to the available information listing Chinese experts in public sectors or clients and academic researches with rich transportation PPP projects experiences or expressed interests in PPP. The questionnaire was pilot tested to ensure that it was practical. The initial draft was presented to a group of international research professionals from the University of Maryland, College Park, USA, Nanyang Technology University of Singapore, and International Finance Corporation, the private industry arm of the World Bank based in Washington, D.C., USA.

The final questionnaire comprises three parts. The first part seeks background information about the respondents and general issues about PPP projects. The second part deals with driving factors and performance objectives about PPP projects. The third part investigates performance indicators and performance management within PPP projects. This paper focuses on the identification of the driving factors from the perspective of the public sector or clients. Likert style rating questions, using a fivepoint scale, were used to elicit respondents' opinions of the significance of each nominated factor based on the public perspective. The scale intervals are interpreted as follows: (1) Can be ignored or not important; (2) Possibly important; (3) Important; (4) Very important; (5) Most important.

A total of 356 questionnaires were sent out. 57 respondents returned complete questionnaires. The effective return rate (16.01 per cent) was higher than that of earlier PPP survey researches which achieved a response rate of 12, and 9.4 per cent respectively; refer to Li et al. (2005b) and Salman et al. (2007). The response was therefore deemed adequate for the purposes of data analysis. The demographics in the survey response included the relatively high proportion of government agency and public enterprise experts involved in PPP's as compared with expert responses from central and local governments (Table 3).

Table 3. Survey Respondents' Roles in Transportation PPP Projects

\begin{tabular}{l|c|c}
\hline \multicolumn{1}{c|}{ Role } & Frequency & Per cent \\
\hline Central government & 5 & 8.77 \\
\hline Local government & 16 & 28.07 \\
\hline Public client or enterprise & 13 & 22.81 \\
\hline Academic researcher & 23 & 40.35 \\
\hline Total & 57 & 100 \\
\hline
\end{tabular}

\subsection{Research results}

\section{1) Data consistency}

Reliability analysis was conducted to test the internal consistency of the survey variable data. Cronbach's Alphas are $0.812(F$-statistic $=13.863$, sig. $=0.000)$ for driving factors. It is much higher than the 0.70 of Nunnally's (1978) guideline and Zhang's (2006) similar research, which suggests that, in the early stages of research on predict tests or hypothesized measures of a construct, reliability of 0.70 or higher should suffice.

\section{2) Agreement on driving factors}

There is also a need to examine the level of agreement between respondents from the public and academic sectors in the rating of the significances of the driving factors. This is done by conducting a Mann Whitney $U$ test to determine whether the mean significance of each factor is equal across the public and academic sectors. The hypotheses are as follows:

$H_{o}=$ mean significance of each factor is equal between any two sectors

$H_{a}=$ mean significance of each factor is different between any two sectors

The statistic of the Mann Whitney $U$ test is $U$, which is compared to a table of critical values based on the sample size of each group. If the value of $U$ exceeds its critical point at some significance level (usually 0.05) it means that there is evidence to reject the null hypothesis and accept the alternative hypothesis (Zhang 2006). The test results are summarized in Table 4, which indicates there is no statistical difference between public and private sectors. Hence the survey data and results can be viewed as e all and one.

\section{3) Ranking of driving factors for adopting transportation PPP projects}

The survey rankings of respondents' opinions of the driving factors of PPPs are listed in Table 5. For the 15 factors offered to respondents, the mean response rating values (for all respondents) range from 4.16 (Acceptable

Table 4. Mann Whitney $U$ test of Driving Factors

\begin{tabular}{c|c|c}
\hline No. & $\begin{array}{c}\text { Asymp. significance } \\
\text { (2 tiled) }\end{array}$ & $\begin{array}{c}\text { Exact significance } \\
\text { (1 tiled) }\end{array}$ \\
\hline F1 & 0.935 & 0.493 \\
\hline F2 & 0.537 & 0.290 \\
\hline F3 & 0.131 & 0.071 \\
\hline F4 & 0.185 & 0.096 \\
\hline F5 & 0.342 & 0.189 \\
\hline F6 & 0.513 & 0.263 \\
\hline F7 & 0.409 & 0.205 \\
\hline F8 & 0.969 & 0.492 \\
\hline F9 & 0.614 & 0.311 \\
\hline F10 & 0.330 & 0.171 \\
\hline F11 & 0.861 & 0.444 \\
\hline F12 & 0.571 & 0.291 \\
\hline F13 & 0.412 & 0.216 \\
\hline F14 & 0.876 & 0.442 \\
\hline F15 & 0.954 & 0.488 \\
\hline
\end{tabular}


Table 5. The Scores and Rankings of Driving Factors

\begin{tabular}{c|c|c|c|c|c|c|c|c|c}
\hline \multirow{2}{*}{$\begin{array}{c}\text { Driving } \\
\text { factors }\end{array}$} & \multicolumn{3}{|c|}{ Academia } & \multicolumn{3}{c|}{ Public sector } & \multicolumn{3}{c}{ Overall } \\
\cline { 2 - 11 } & Mean & SD & Rank & Mean & SD & Rank & Mean & SD & Rank \\
\hline F1 & 4.15 & 0.79 & 1 & 4.17 & 0.83 & 1 & 4.16 & 0.79 & 1 \\
\hline F2 & 3.98 & 0.86 & 2 & 4.17 & 0.90 & 1 & 4.02 & 0.78 & 2 \\
\hline F3 & 3.98 & 0.8 & 2 & 3.58 & 0.72 & 4 & 3.90 & 0.87 & 3 \\
\hline F4 & 3.87 & 0.91 & 4 & 3.50 & 0.80 & 6 & 3.79 & 0.89 & 4 \\
\hline F5 & 3.59 & 0.84 & 5 & 3.92 & 1.08 & 3 & 3.66 & 1.06 & 5 \\
\hline F6 & 3.67 & 1.11 & 6 & 3.42 & 0.90 & 8 & 3.62 & 0.89 & 6 \\
\hline F7 & 3.65 & 0.92 & 7 & 3.50 & 1.17 & 6 & 3.62 & 0.97 & 6 \\
\hline F8 & 3.54 & 1.11 & 8 & 3.42 & 1.00 & 8 & 3.52 & 1.08 & 8 \\
\hline F9 & 3.30 & 1.05 & 9 & 3.42 & 1.08 & 8 & 3.33 & 1.04 & 9 \\
\hline F10 & 3.24 & 1.06 & 10 & 3.58 & 1.08 & 4 & 3.31 & 1.06 & 10 \\
\hline F11 & 3.15 & 1.21 & 12 & 3.17 & 1.16 & 11 & 3.16 & 1.00 & 11 \\
\hline F12 & 3.22 & 1.03 & 11 & 2.92 & 0.94 & 12 & 3.16 & 1.19 & 11 \\
\hline F13 & 3.13 & 0.86 & 13 & 2.67 & 1.30 & 14 & 3.03 & 0.97 & 13 \\
\hline F14 & 2.80 & 0.98 & 14 & 2.92 & 1.24 & 12 & 2.83 & 1.02 & 14 \\
\hline F15 & 2.74 & 1.06 & 15 & 2.67 & 1.07 & 14 & 2.72 & 1.05 & 15 \\
\hline
\end{tabular}

quality) down to 2.72 (Private sector can earn government sponsorship, guarantee and tax reduction). No factor mean value scores fell into the "extremely important" $(>4.50)$ and "fairly important" $(<2.50)$ categories, which shows that all driving factors in this research are important.

As shown in Table 5, improvement of the performance of public transportation projects, delivery of better public service and solving the problem of budget restraint are all very important $(>3.50)$ factors. China's public sector expects to achieve greater project performance (e.g. time, quality, and cost) by cooperating with private sectors because many past Chinese public projects provided by traditional procurement methods (e.g. Design-Build) failed due to delays or cost overruns. The problem of public sector budget constraints besets many municipal and other public sector authorities, especially in terms of improving public infrastructure and delivering essential services. Clearly, the attractiveness of PPP in addressing this problem is fully recognized by respondents. The commercialization of infrastructure is also attractive for Chinese public sectors, which is a very specific factor in Chinese context and also can promote the government structural reform in China. Although the cases presented in this paper all indicate that transferring risks is important for public sectors, its significance is relatively low in this survey. The reason may be that the improvement of the performance of public transportation projects would probably reduce related risks and assure that the project is under good control, which can also explain that the score of making profit from public service is also low. Meanwhile the low score of improving technology level or gaining technology transfer indicates that the public sector prefers to adopt mature technology in the important transportation projects to ensure success. Therefore, the additional facilities/service beyond requirement from private sector and commitments for private sectors are less important.

\section{Analysis of driving factors}

\subsection{Basic Step and Adequacy of Factor Analysis}

Factor analysis is a statistical approach that can be used to verify the conceptualization of a hypothesis by analyzing interrelationships among a large number of variables and to explain these variables in terms of their common underlying dimensions by condensing the information contained in a number of original variables into a smaller set of dimensions with a minimum loss of information (Li et al. 2005a; Zhang 2006). Factor analysis can also be used to determine the relative importance amongst these dimensions. The survey response data was subjected to this technique to determine whether or not groupings of the driving factors in the perceptions of the transportation PPP could be established. If such groupings can be identified, they could provide valuable guidance to the Chinese public sector in pursuing development of PPP policy in MTS, and to the private sector in the preparation of the business case for transportation projects. There are four basic steps for factor analysis: (1) generation of the correlation matrix; (2) extraction of initial factors; (3) rotation and interpretation; and (4) construction of scales or factor scores for further analyses. Please refer to Zeller, Carmines (1980) and Pett et al. (2003) for details on how to conduct a factor analysis.

The survey data should be examined to see whether it is appropriate to use factor analysis by conducting the Kaiser-Meyer-Olkin (KMO) test and/or the Barlett's test of sphericity. The two tests indicate the strength of the relationship among variables and provide a minimum standard that should be passed before a factor analysis is conducted. The KMO measure of sampling adequacy is an index for comparing the magnitudes of the observed correlation coefficients to the magnitudes of the partial correlation coefficients. Its value should be greater than 0.5 for a satisfactory factor analysis to proceed (Pett et al. 2003; Zhang 2006). The Bartlett's test of sphericity examines the null hypothesis that the correlation matrix is an identity matrix (that is, the variables in the population correlation matrix are uncorrelated), which would indicate that the factor model is inappropriate (Pett et al. 2003). 


\subsection{Factor Analysis Results}

Table 6 shows the results of the KMO and Bartlett's tests for all of the driving factors. The KMO measure is 0.646 , indicating the data are adequate for factor analysis. The observed significance level of the Bartlett's test of sphericity is 0.000 , which is small enough to reject the null hypothesis and supports a factor analysis for the data. The two tests draw the same conclusion regarding whether a factor analysis is appropriate. Therefore, a factor analysis can be conducted for all of the factors.

Table 6. KMO and Bartlett's Test

\begin{tabular}{c|c|c|c}
\hline \multirow{2}{*}{$\begin{array}{c}\text { Kaiser-Meyer-Olkin } \\
\text { Measure of Sampling } \\
\text { Adequacy }\end{array}$} & \multicolumn{3}{|c}{ Bartlett's Test of Sphericity } \\
\cline { 2 - 4 } & $\begin{array}{c}\text { Approx. } \\
\text { Chi-Square }\end{array}$ & DF & Significance \\
\hline 0.646 & 287.411 & 105 & 0.000 \\
\hline \multicolumn{4}{r|}{ DF $=$ Degree of freedom } \\
\hline
\end{tabular}

The principal components and varimax rotation were used to extract highly correlated factors into a small number of major components (dimensions). Fig. 4 shows the scree plot of the factor analysis for all of the driving factors. The scree plot graphs the eigenvalue against the number of components. Each successive component accounts for decreasing amounts of the total variance. Five principal components are extracted by specifying eigenvalues (i.e., the variances of the principal components) greater than 1. As shown in Table 7, the five extracted components cumulatively explain $66.257 \%$ of the total variance. Thus, a model with five factor groupings may be adequate to represent the data.

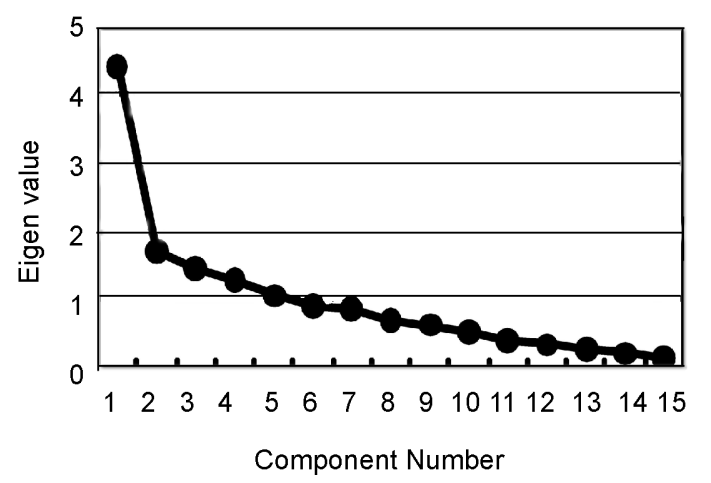

Fig. 4. The Scree Plot for All of the 15 Driving Factors

Table 8 is the rotated component matrix, in which to make the output easier to read absolute values less than 0.5 are suppressed. Each row of Table 8 contains component loadings, the correlations between each variable, and the component (the dimension of the driving factors). The component loadings indicate which factor group belongs to which component. The first component has the largest variance and therefore can explain the problem most effectively. The second component is independent of the first component and contains as much of the remaining information in all best-value risk management objectives as possible, and so on.

Table 7. Total Variance Explained by Principal Component Analysis

\begin{tabular}{c|c|c|c|c|c|c}
\hline \multirow{2}{*}{ Component } & \multicolumn{3}{|c|}{ Initial Eigenvalues } & \multicolumn{3}{c}{ Rotation Sums of Squared Loadings } \\
\cline { 2 - 7 } & Total & \% of Variance & Cumulative (\%) & Total & \% of Variance & Cumulative (\%) \\
\hline 1 & 4.428 & 29.518 & 29.518 & 2.828 & 18.856 & 18.856 \\
\hline 2 & 1.701 & 11.338 & 40.856 & 2.271 & 15.140 & 33.995 \\
\hline 3 & 1.459 & 9.726 & 50.583 & 2.166 & 14.443 & 48.439 \\
\hline 4 & 1.291 & 8.609 & 59.191 & 1.338 & 8.992 & 57.361 \\
\hline 5 & 1.060 & 7.065 & 66.257 & 1.334 & 8.896 & 66.257 \\
\hline
\end{tabular}

Table 8. Rotated Component Matrix for Total 15 Driving Factors

\begin{tabular}{|c|c|c|c|c|c|c|}
\hline \multirow{2}{*}{ Factor groupings } & \multirow{2}{*}{$\begin{array}{l}\text { Driving } \\
\text { Factors }\end{array}$} & \multicolumn{5}{|c|}{ Components } \\
\hline & & 1 & 2 & 3 & 4 & 5 \\
\hline \multirow[t]{5}{*}{ More public benefits } & F13 & 0.866 & - & - & -- & -- \\
\hline & F11 & 0.681 & - - & - - & - - & -二 \\
\hline & F12 & 0.646 & -- & - & - & -- \\
\hline & F8 & 0.602 & - & -- & - & - \\
\hline & F14 & 0.584 & -— & -二 & -二 & -二 \\
\hline \multirow[t]{3}{*}{ Better public service } & F3 & - & 0.841 & -- & -— & -二 \\
\hline & F1 & -— & 0.751 & - & - & -- \\
\hline & F6 & -- & 0.737 & -- & - - & -二 \\
\hline \multirow{4}{*}{$\begin{array}{l}\text { Avoidance of financial and risk } \\
\text { management constraints }\end{array}$} & F10 & - & - & 0.757 & -— & -- \\
\hline & F5 & -- & - & 0.744 & -- & -二 \\
\hline & F15 & - - & - & 0.558 & - - & -— \\
\hline & F7 & - & - & 0.530 & -— & -- \\
\hline \multirow[t]{2}{*}{ Performance improvement of projects } & F4 & -— & -二 & -— & 0.772 & -二 \\
\hline & F2 & - & - & - & 0.727 & -— \\
\hline Commercialization & F9 & -— & -— & -— & -— & 0.844 \\
\hline
\end{tabular}


The five Chinese driving factor groupings in MTS can be viewed as the purpose of Chinese government to promote PPP model, which are interpreted as followed:

(1) Factor grouping 1 represents more public benefits including better technology and economy.

(2) Factor grouping 2 represents providing better public service.

(3) Factor grouping 3 is public sector avoidance of financial and risk management restraints.

(4) Factor grouping 4 is project performance improvement.

(5) Factor grouping 5 represents promoting the commercialization of infrastructure development.

\subsection{Factor Grouping Description}

Factor analysis of these driving factors has determined 5 major common dimensions of the public sectors' purpose to develop transportation infrastructure through PPPs. The key factors that measure each of these dimensions are described as followed.

1) More public benefits

Factor grouping 1 accounts for 18.86 per cent of the total variance of driving factor variance includes five key factors,

(1) Life-cycle cost reduction.

(2) Promoting local economic development.

(3) Making profit from public service.

(4) Improving technology level or gaining technology transfer.

(5) Public sector can acquire additional facilities/ service beyond requirement from private sector.

Higher loadings are given to technology improvement and transfer $($ sig. $=0.866)$, which indicates that the public sector expect to see new technology at work and benefitting local economies ( $\mathrm{sig}$. $=0.681$ ). The consequent expectations of public sector are life-cycle cost reducing $($ sig. $=0.602)$, making profit $($ sig. $=0.646)$, and probably acquiring additional support from private sectors ( $\mathrm{sig}$. $=0.584$ ), which are all related to the adoption of advanced technology including invisible technology (e.g. management skill). A PPP arrangement could facilitate creative and innovative approaches to the delivery of public services in two ways. PPP procurement approach specifies desired outcomes rather than detailed definitions of inputs. This allows bidders to compete on the basis of their ability to develop unique and creative approaches to the delivery of the required project (Birnie 1999).

The inference to be drawn from this factor grouping is that the Chinese public sectors treat PPP as a panacea for the Chinese infrastructure development problems. The implication is that, the sustainable development of PPP model in Chinese MTS strongly depends on the continuous success in real projects.

\section{2) Better public service}

Factor grouping 2 accounts for 15.14 per cent of the total variance of driving factor variance, and represents three key factors,

(1) Acceptable quality of project.
(2) Quality public service.

(3) Provide timelier and more convenient service for society.

These components are all associated with quality public service, which is given to a high loading (sig. = 0.841), which demonstrates that improving the transportation facility service level to satisfy local, regional, and national needs is an important driving factor in China that is closely related with acceptable quality (sig. $=0.751$, e.g. mobility level), timelier and more convenient service (sig. $=0.737$, e.g. less congestion).

The inference to be drawn from this factor grouping is that the operation stage of a transportation PPP project is critical for the success. The goal of implementing these projects is to improve the efficiency of transportation system to achieve time-saving, convenience, and costsaving, which should be built on the basis of good project operation and maintenance. In fact, to achieve best value for public service and product is the ultimate objective for PPPs (Zhang, 2006; Sobotka and Czarnigowska, 2008). The best value is defined as the maximum achievable outcome from the development of an infrastructure project by Gransberg and Ellicott (1997). In PPPs, best-value emphasizes quality, efficiency/effectiveness, Value for Money (VfM) and performance standards (Akintoye et al. 2003).

3) Public sector avoidance of financial and risk management constraints

Factor grouping 3 accounts for 14.44 per cent of the total variance of driving factor variance, and represents four key factors,

(1) Satisfying the need of public facilities.

(2) Solving the problem of public sector budget restraint.

(3) Transferring risk to private sector.

(4) Private sector can earn government sponsorship, guarantee and tax reduction.

Higher loadings are given to resolve the problem of financial constraints (sig. $=0.757)$ and risk management $($ sig. $=0.744)$. These reflect the urgent demands of Chinese public sectors, which include the need of public facilities (sig. $=0.530$ ) and even can give little incentive to private sectors like guarantee and tax reduction (sig. $=0.558$ ). In some UK PPP projects, PPP/PFI procurement can join a non-profitable project and a profitable project as a single contract. For example, to attract private sector investment, Sohail (2000) suggested that one favored solution was to combine sanitation and water supply together as a package for contractors. This arrangement can further solve the problem of governments.

The inference to be drawn from this factor grouping is that the development of PPPs has a close relationship with the macro-political and economic environment, which has been documented by previous researches.

\section{4) Performance improvement of projects}

Factor grouping 4 accounts for 8.99 per cent of the total variance of driving factor variance, and represents two key factors, 
(1) Within budget or saving money in construction and operation.

(2) On-time or earlier project completion.

The great desire of public sectors to improve the performance of transportation PPP projects contains costsaving (sig. $=0.727)$ and time-saving $($ sig. $=0.772)$ with high loadings. An important attractiveness of PPPs for public sector is the ability of private sectors to deliver public service with high performance. As shown in case study, the private partners are always large and wellorganized companies in China because of their experiences and capability. Strong private consortium is viewed as a critical success factor in previous researches (Tiong et al. 1992; Li et al. 2005b). This suggests that private companies wishing to participate in PPP markets should explore other participants' strengths and weaknesses and, where appropriate, join together to form consortia capable of synergizing and exploiting their individual strengths (Li et al. 2005b). Therefore, the public sectors should pay careful attention to the selection of concessionaire and how they might best be encouraged in process of procurement of PPP projects. Therein, the case of the $4^{\text {th }}$ Beijing Metro Line can be considered as a good example.

\section{5) Commercialization}

Factor grouping 5 accounts for 8.89 per cent of the total variance of driving factor variance, which just contains one key factor of commercialization of infrastructure development. As mentioned above, Chinese government regarded PPPs as a tool to promote the urbanization, modernization, commercialization in the development of infrastructure including transportation. As same as most of developing countries, a much more intrusive and demanding form of regulation is required in China. The need for regulation reform is vital, because China is usually characterized by non-competitive industry structures and/or lack of capital market discipline. In such environments, too little market information is revealed and information asymmetries are overwhelming. Therefore, the private sectors that want to invest PPP projects should fully recognize this point, which can help them win the project to provide more efficient and effective delivery.

\subsection{Validity test}

Validity analysis examines whether what is expected to be measured is measured. This means that, if the driving factors grouped in a particular component collectively explain the public sectors' purpose in that dimension, they should significantly correlate with one another. Here, Pearson bivariate correlation analysis is conducted to examine whether relationships between factors exist to ensure validity (Zhang 2006). According to the Pearson's table, the critical values that need to be surpassed to achieve significance for the two-tailed test for a sample of size 57 are around 0.258 and 0.336 for the 0.05 and 0.01 levels, respectively. Pearson bivariate correlation analysis shows that most of the factors that measure a specific dimension of the public sector's purpose are correlated to one other, and therefore, they do measure the purpose in that dimension. The correlations between driving factors in component 1 is shown Table 9. Correlations between driving factors in other components are not provided due to the limitation of space.

Table 9. Pearson Correlations for Component 1 in Factor Analysis for Driving Factors

\begin{tabular}{|c|c|c|c|c|c|c|}
\hline & & F8 & F11 & F12 & F13 & F14 \\
\hline \multirow[t]{3}{*}{$\mathrm{F} 8$} & Pearson Correlation & 1.000 & $0.603^{\mathrm{a}}$ & $0.331^{\mathrm{b}}$ & $0.350^{\mathrm{a}}$ & $0.492^{\mathrm{a}}$ \\
\hline & Sig. (2-tailed) & & 0.000 & 0.011 & 0.007 & 0.000 \\
\hline & $\mathrm{N}$ & 57 & 57 & 57 & 57 & 57 \\
\hline \multirow[t]{3}{*}{ F11 } & Pearson Correlation & $0.603^{\mathrm{a}}$ & 1.000 & $0.344^{\mathrm{a}}$ & $0.479^{\mathrm{a}}$ & $0.366^{\mathrm{a}}$ \\
\hline & Sig. (2-tailed) & 0.000 & & 0.008 & 0.000 & 0.005 \\
\hline & $\mathrm{N}$ & 57 & 57 & 57 & 57 & 57 \\
\hline \multirow[t]{3}{*}{ F12 } & Pearson Correlation & $0.331^{b}$ & $0.344^{\mathrm{a}}$ & 1.000 & $0.448^{\mathrm{a}}$ & 0.193 \\
\hline & Sig. (2-tailed) & 0.011 & 0.008 & & 0.000 & 0.146 \\
\hline & $\mathrm{N}$ & 57 & 57 & 57 & 57 & 57 \\
\hline \multirow[t]{3}{*}{ F13 } & Pearson Correlation & $0.350^{\mathrm{a}}$ & $0.479^{\mathrm{a}}$ & $0.448^{\mathrm{a}}$ & 1.000 & $0.304^{\mathrm{b}}$ \\
\hline & Sig. (2-tailed) & 0.007 & 0.000 & 0.000 & & 0.020 \\
\hline & $\mathrm{N}$ & 57 & 57 & 57 & 57 & 57 \\
\hline \multirow[t]{3}{*}{ F14 } & Pearson Correlation & $0.492^{\mathrm{a}}$ & $0.366^{\mathrm{a}}$ & 0.193 & $0.304^{\mathrm{b}}$ & 1.000 \\
\hline & Sig. (2-tailed) & 0.000 & 0.005 & 0.146 & 0.020 & $\longrightarrow$ \\
\hline & $\mathrm{N}$ & 57 & 57 & 57 & 57 & 57 \\
\hline $\begin{array}{l}a \\
b\end{array}$ & $\begin{array}{l}\text { Correlat } \\
\text { Correlat }\end{array}$ & & 0.011 & vel (2-1 & $\begin{array}{l}\text { ailed). } \\
\text { ailed). }\end{array}$ & \\
\hline
\end{tabular}

\section{Conclusions}

Public-private partnerships have been practiced in China for years and they contribute to the national and local infrastructure development by providing investments, advanced technology, and management skills. However, the development and successful implementation of PPP in Chinese MTS rely on the achievement of the objective/purpose of public sectors when PPP being initiative, which make private sectors face strong challenges to satisfy the demands of public sectors. Therefore, here is a need to thoroughly identify the driving factors of PPP from the viewpoint of public sectors, which can be helpful for both public and private parties to improve their understanding in planning and implementation of PPP projects to achieve a win-win result.

Based on the case study and literature review, 15 driving factors of PPP projects on the perspective of Chinese public sectors were identified. The relative importance of 15 PPP driving factors was investigated through an opinion survey conducted within China. The top ten attractive factors for Chinese public sectors to develop PPP model in MTS are those PPP can provide acceptable quality of project, save money in the stage of construction and operation, deliver quality public service, complete the projects on time, solve the problem of public capital scarcity, make service timelier and more convenient, satisfy the demands of more public service, reduce life-cycle cost including administration cost, commercialization of 
infrastructure development, and transfer the risks to private sectors.

Factor analysis of these driving factors has determined the major common dimensions of the public sectors' purpose to develop transportation infrastructure through PPPs and the key factors that measure each of these dimensions. The Mann Whitney $U$ test shows that the public and academic sectors in the survey consider driving factors rather similarly, and the KMO test, Bartlett's test, validity, and reliability analyses confirm the adequacy and quality of the survey, the soundness of the factor analysis, and the internal consistency of the driving factors that measure each dimension of the public sectors' purpose. The five most important public sectors' purpose to adopt PPP in transportation projects can be concluded as to obtain more public benefits, to seek better public service, to resolve the problem of financial restraints and inefficient service delivery, and to promote the commercialization of Chinese infrastructure development.

These important public sectors' purposes, representing the attractive characteristic of PPP model for the Chinese government to adopt this kind of procurement method, are significant for those public partners (e.g. government departments, public clients, public enterprises, etc.) to see how to encourage the private sector to craft innovative project delivery approaches to offer the best value, and also should be considered by private sectors to see how to win the Chinese PPP contract, as well as maximize profit generated from an investment through long term contractual arrangement.

\section{References}

Akintoye, A.; Beck, M.; Cliff, H.; Chinyio, E.; Asenova, D. 2001. The financial structure of private finance initiative projects, in Proceedings: 17th ARCOM Annual Conference, September, 2001, Salford, 1: 361-369.

Akintoye, A.; Hardcastle, C.; Beck, M.; Chinyio, E.; Darinka Asenova, D. 2003. Achieving best value in private finance initiative project procurement, Construction Management and Economics 21: 461-470. doi: $10.1080 / 0144619032000087285$

Birnie, J. 1999. Private Finance Initiative (PFI) - UK construction industry response, Journal of Construction Procurement 5(1): 5-14.

Chan, W. T.; Chen, C.; Messner, J. I.; Chua, D. K. H. 2003. Interface management for China's build-operate-transfer projects, ASCE: Journal of Construction Engineering and Management 133(6): 645-655.

Chen, A.; Subprasom, K. 2007. Analysis of regulation and policy of private toll roads in a build-operate-transfer scheme under demand uncertainty, Transportation Research Part A 41: 537-558. doi:10.1016/j.tra.2006.11.009

Chen, C.; Doloi, H. 2008. BOT application in China: Driving and impeding factors, International Journal of Project Management 26(4): 388-398. doi:10.1016/j.ijproman.2007.07.002

Dimitriou, H. T.; Trueb, O. 2005. Transportation megaprojects, globalization, and place-making in Hong Kong and South China, Transportation. Research Record: Journal of the Transportation Research Board, No. 1924, Transportation Research Board of the National Academies, Washington, D.C., 59-68.
Ehrlich, M.; Tiong, R. T. L. 2008. Modelling country reliability in public private partnership infrastructure projects, in Proceedings, 25th International Symposium on Automation and Robotics in Construction, E. K. Zavadskas, A. Kaklauskas, M. J. Skibniewski (Eds.). Vilnius, Lithuania, June 26-29, 2008, Vilnius: Technika, 751-758. doi:10.3846/isarc.20080626.751

Francois, F. B. 2001. Introduction in Intelligent Transportation Primer. Donna C. Nelson (Ed.). Institute of Transportation Engineers: Washington, DC, 1-7.

Gransberg, D. D.; Ellicott, M. A. 1997. Best value contracting criteria, Cost Engineering 39(6): 31-34.

Kumaraswamy, M. M.; Anvuur, A. M. 2008. Selecting sustainable teams for PPP projects, Building and Environment 43(6): 999-1009. doi:10.1016/j.buildenv.2007.02.001

Lawther, W. C. 2005. Public-private partnerships in transportation policy: the case of advanced traveler information systems, International Journal of Public Administration 28: 1117-1134. doi:10.1080/01900690500290660

Li, B. Akintoye, A.; Edwards, P. J.; Hardcastle, C. 2005a. Perceptions of positive and negative factors influencing the attractiveness of PPP/PFI procurement for construction projects in the UK: Findings from a questionnaire survey, Engineering, Construction and Architecture Management 12(2): 125-148. doi:10.1108/09699980510584485

Li, B.; Akintoye, A.; Edwards, P. J.; Hardcastle, C. 2005 b. Critical success factors for PPP/PFI projects in the UK construction industry, Construction Management and Economics 23: 459-471. doi:10.1080/01446190500041537

Li, J. H.; Li, Q. M. 2007. Financial risk assessment of Chinese PPP projects in urban rail transit: case study of the $4^{\text {th }}$ Beijing Metro Line, Construction Economy (10): 23-26 (in Chinese).

Majamaa, W.; Junnila, S.; Doloi, H.; Niemistö, E. 2008. Enduser oriented public-private partnerships in real estate industry, International Journal of Strategic Property Management 12(1): 1-17. doi:10.3846/1648-715X.2008.12.1-17

Meng, X. 2002. Guarantees for contractor's performance and owner's payment in China, ASCE: Journal of Construction Engineering and Management 128(3): 232-237. doi:10.1061/(ASCE)0733-9364(2002)128:3(232)

Nunnally, J. O. 1978. Psychometric Theory. $2^{\text {nd }}$ edition. New York: McGraw-Hill.

Pessoa, A. 2008. Public-private partnerships in developing countries: are infrastructure responding to the New ODA Strategy? Journal of International Development 20: 311325. doi:10.1002/jid.1416

Pett, N. A.; Lackey, N. R.; Sullivan, J. J. 2003. Making sense of factor analysis: The use of factor analysis for instrument development in health care research. Thousand Oaks: Sage Publications Inc.

Salman, A. F. M.; Skibniewski, M. J.; Basha, I. 2007. BOT viability model for large-scale infrastructure projects, ASCE: Journal of Construction Engineering and Management 133(1): 50-63. doi:10.1061/(ASCE)0733-9364(2007)133:1(50)

Seneviratne, P. N. 2006. Road sector development in China and India: trends and implications, Transportation Research Record: Journal of the Transportation Research Board, No. 1954, Transportation Research Board of the National Academies, Washington, D.C., 5-21. 
Skietrys, E.; Raipa, A.; Bartkus, E. V. 2008. Dimensions of the efficiency of public-private partnership, Inzinerine Ekonomika - Engineering Economics (3): 45-50.

Sobotka, A.; Czarnigowska, A. 2008. Target costing in public construction projects, in The 9th International conference "Modern Building Materials, Structures and Technologies": Selected papers, Vol. 1, M. J. Skibniewski, P. Vainiūnas, E. K. Zavadskas, etc. May 16-18, 2007, Vilnius, Lithuania. Vilnius: Technika, 375-380.

Sohail, M. 2000. PPP and the Poor in Water and Sanitation Interim Finds. Research report: Engineering, and Development Centre, Loughborough University, Loughborough.

Tieva, A.; Junnonen, J.-M. 2009. Proactive contracting in Finnish PPP projects, International Journal of Strategic Property Management 13(3): 219-228. doi:10.3846/1648-715X.2009.13.219-228

Tiong, R. L. K.; Yeo, K.; McCarthy, S. C. 1992. Critical success factors in winning BOT projects, ASCE: Journal of Construction Engineering and Management 118(2): 217 228. doi:10.1061/(ASCE)0733-9364(1992)118:2(217)

UNIDO. 1996. Guidelines for infrastructure development through build-operate-transfer (BOT) projects. Vienna: UNIDO.

Wang, S. Q.; Tiong, R. L. K.; Ting, S. K.; Ashley, D. 2000. Evaluation and Management of Political Risks in China's BOT Projects, ASCE: Journal of Construction Engineering and Management 126(3): 242-250. doi:10.1061/(ASCE)0733-9364(2000)126:3(242)
Xie, W. D.; He, W. 2006. PPP pattern financing in urban mass transit realm of China, Urban Transit Transportation (3): 1-4 (in Chinese).

Yuan, J. F.; Zeng, A. J. Y.; Skibniewski, M. J.; Li, Q. M. 2009. Selection of performance objectives and key performance indicators in public-private partnership projects to achieve value for money, Construction Management and Economics 27(3): 253-270. doi:10.1080/01446190902748705

Zeller, R. A.; Carmines, E. G. 1980. Measurement in the social science. London: Cambridge University Press.

Zhang, W. R.; Wang, S. Q.; Tiong, R. L. K.; Ting, S. K.; Ashley, D. 1998. Risk management of Shanghai's privately financed Yan'an Donglu tunnels, Engineering, Construction and Architecture Management 5(4): 399-499. doi:10.1046/j.1365-232X.1998.54083.X

Zhang, X. Q. 2005. Critical success factors for public private partnerships in infrastructure development, ASCE: Journal of Construction Engineering and Management 131(1): 3-14. doi:10.1061/(ASCE)0733-9364(2005)131:1(3)

Zhang, X. Q. 2006. Factor analysis of public clients' best-value objective in public-privately partnered infrastructure projects, ASCE: Journal of Construction Engineering and Management 132(9): 956-965. doi:10.1061/(ASCE)0733-9364(2006)132:9(956)

Zhao, Z. L. 2006. Risk analysis of Chinese transportation BOT projects: Case Study of Nanjing Yangtze River Tunnel, Economic Forum (10): 94-96 (in Chinese).

\section{PAGRINDINIAI KINIJOS VIEŠOJO IR PRIVATAUS BENDRADARBIAVIMO VEIKSNIAI METROPOLIJOS TRANSPORTO SISTEMŲ PROJEKTUOSE VIEŠOJO SEKTORIAUS POŽIŪRIU}

\section{J. Yuan, M. J. Skibniewski, Q. Li, and J. Shan}

S a n tra k a

Pastaruoju metu Kinijai reikia daug daugiau finansavimo transporto infrastruktūrai plètoti, nei gali suteikti vien šalies vyriausybè. Jos galimybès veiksmingai ir efektyviai teikti viešąsias paslaugas tiriamos bei vertinamos įvairiais lygiais. Skatinamas privačiu investuotojų įtraukimas į metropolijos transporto sistemų (MTS) plètrą taikant viešojo ir privataus bendradarbiavimo modeli. Tačiau Kinijos dinamiška ir kompleksinė politine, finansinè bei teisinè aplinka priverčia privatų sektorių derintis prie egzistuojančios tvarkos, atsižvelgiant i pagrindinius viešojo ir privataus bendradarbiavimo veiksnius, kurie padidintų projekto sėkmès tikimybę. Straipsnyje pateikiami du Kinijos metropolijos transporto sistemų plètros pavyzdžiai. Remiantis nagrinėjamais pavyzdžiais ir išsamia literatūros analize, iš Kinijos viešojo sektoriaus pozicijų identifikuota 15 pagrindinių veiksnių, susijusių su viešojo ir privataus bendradarbiavimo projektais. Buvo atlikta apklausa, orientuota i viešaji sektorių, išanalizuota, kaip pagrindiniai veiksniai suvokiami ir pritaikomi. Atliekant kiekvieno iš šių veiksnių santykinių reikšmingumų statistinę analizę, buvo apibrèžti penki pagrindiniai Kinijos viešojo sektoriaus tikslų aspektai, plètojant viešojo ir privataus bendradarbiavimo schemas, ir pagrindiniai rodikliai, ívertinantys šiuos tikslus skaitine išraiška. Minètų tikslų nustatymas ir pagrindinių skaitinių rodiklių ịvertinimas galètų būti naudingi, skatinant privatų sektorių prisidèti prie infrastruktūros valdymo, galètų padèti koncentruoti bei nukreipti privataus sektoriaus jègas kokybiškoms viešojo sektoriaus paslaugoms teikti, remiantis abipusiškai naudingomis ilgalaikemis sutartimis.

Reikšminiai žodžiai: viešasis ir privatusis bendradarbiavimas, metropolijos transporto sistemos, sprendimo rodikliai, rodiklių analizè, viešasis sektorius, infrastruktūros plètra.

Jing-Feng YUAN. Member of research faculty in the Institute of Construction Management and Real Estate, Dept. of Construction and Real Estate, School of Civil Engineering Southeast University, Nanjing, China. He was a visiting researcher at the University of Maryland, College Park, USA. His research interests are in Public Private Partnership, risk management, construction safety, and sustainable management.

Miroslaw J. SKIBNIEWSKI. The A. James Clark Endowed Chair Professor of Construction Engineering and Project Management at the Dept. of Civil and Environmental Engineering at the University of Maryland in College Park, USA. Member of American Society of Civil Engineers (ASCE); a founding member, co-director and past president of International Association for Automation Robotics in Construction (IAARC); and an affiliate of International Council for Building Research Studies and Documentation (CIB). His research interests include information technology in construction applications, e-commerce technologies, construction automation and robotics, and wireless technology in construction. 
Qiming LI. Professor and Head of Dept. of Construction and Real Estate, School of Civil Engineering Southeast University, Nanjing, China. Member of Project Management Professional Assessment Committee of Ministry of Construction, China; Fellow of Chartered Institute of Building $(F C I O B)$; Fellow of Royal Institution of Chartered Surveyors (FRICS); and the Chairman of Real Estate Economic Academic Committee, Civil Engineering and Architectural Society, Jiangsu Province, China. His research interests include risk and safety management in construction, sustainable management, real estate, housing development.

Jin SHAN. A PhD student in the School of Transportation, Southeast University, Nanjing, China. His research interests are in transportation planning and congestion management. 